\title{
Febrile attacks triggered by milk allergy in an infant with mevalonate kinase deficiency
}

\author{
Hideyuki Nakashimai ${ }^{1} \cdot$ Fumihito Miyake $^{1} \cdot$ Shigeru Ohki $^{1} \cdot$ Seira Hattori $^{2}$ • \\ Tadashi Matsubayashi $^{2} \cdot$ Kazushi Izawa $^{3} \cdot$ Ryuta Nishikomori $^{3} \cdot$ Toshio Heike $^{3}$. \\ Yoshitaka Honda ${ }^{3} \cdot$ Yosuke Shigematsu $^{4}$
}

Received: 2 April 2016 / Accepted: 28 June 2016 / Published online: 7 July 2016

(C) The Author(s) 2016. This article is published with open access at Springerlink.com

\section{To the Editor,}

Mevalonate kinase deficiency (MKD) is a rare autoinflammatory disease characterized by recurrent fever, lymphadenopathy, hepatomegaly, splenomegaly, skin lesions, abdominal pain, and diarrhea [1-4] and may lead to neurological involvement and death $[1,5]$. The febrile attack is commonly triggered by infection, vaccines, and stress. We report an infant with MKD whose febrile attacks were triggered by milk allergy.

The female patient was born by cesarean section because of obstructed labor at a gestational age of 39 weeks and 4 days with a birth weight of $2612 \mathrm{~g}$. No signs of infection were seen in the gestation and peripartum period. Her father was Hispanic and her mother Asian. At 3 days of age, her body temperature rose above $38{ }^{\circ} \mathrm{C}$, and the next day she was transferred to the neonatal intensive care unit of Seirei Hamamatsu General Hospital, Shizuoka, Japan. On admission, the patient's activity was maintained, and she could feed breast and formula milk adequately. Body temperature was $39.0^{\circ} \mathrm{C}$ and mild tachypnea was observed. No aphthous ulcers in the oral cavity were observed. Breath sounds were normal and heart murmurs were not audible. The abdomen

Hideyuki Nakashimai

h-nakashima@mvd.biglobe.ne.jp

1 Department of Neonatology, Seirei Hamamatsu General Hospital, 2-12-12 Sumiyoshi, Naka-ku, Hamamatsu, Shizuoka 430-8558, Japan

2 Department of Pediatrics, Seirei Hamamatsu General Hospital, Hamamatsu, Shizuoka, Japan

3 Department of Pediatrics, Graduate School of Medicine, Kyoto University, Kyoto, Japan

4 Department of Health Science, Faculty of Medical Sciences, University of Fukui, Fukui, Japan was slightly distended but hepatosplenomegaly was not observed. Laboratory data showed: white blood cell count $15,010 / \mu \mathrm{L}$, red blood cell count $379 \times 10^{4} / \mu \mathrm{L}$, hemoglobin $12.4 \mathrm{~g} / \mathrm{dL}$, hematocrit $36.7 \%$, platelet count $30.3 \times$ $10^{4} / \mu \mathrm{L}$, total protein $6.4 \mathrm{~g} / \mathrm{dL}$, albumin $3.0 \mathrm{~g} / \mathrm{dL}$, total bilirubin $2.5 \mathrm{mg} / \mathrm{dL}$, aspartate aminotransferase $112 \mathrm{IU} / \mathrm{L}$, alanine aminotransferase $67 \mathrm{IU} / \mathrm{L}$, lactate dehydrogenase $660 \mathrm{IU} / \mathrm{L}$, creatine phosphokinase $63 \mathrm{IU} / \mathrm{L}$, blood urea nitrogen $5 \mathrm{mg} /$ $\mathrm{dL}$, creatinine $0.30 \mathrm{mg} / \mathrm{dL}$, C-reactive protein $13.3 \mathrm{mg} / \mathrm{dL}$, immunoglobulin (Ig) G $945 \mathrm{mg} / \mathrm{dL}$, IgA $3 \mathrm{mg} / \mathrm{dL}$ and IgM $91 \mathrm{mg} / \mathrm{dL}$. Neither pyuria nor pleocytosis were present. Ophthalmological examination confirmed that there was no uveitis. At 6 days old, small red papules appeared on the skin of the patient's entire body. No significant pathogens were cultured from her urine, blood, stool, spinal fluid or pharyngeal secretion and no virus was isolated from her stool and pharyngeal secretion.

Antibacterial and antiviral agents were infused but the fever persisted. At the age of 16 days, the patient became sluggish and abdominal distension increased with watery diarrhea. C-reactive protein markedly elevated to $41.2 \mathrm{mg} /$ dL. Computed tomography scan showed dilatation of the intestine, edematous intestinal walls and retention of the intestinal contents. Serum IgE increased to $367.8 \mathrm{IU} / \mathrm{mL}$ and IgE specific for cow's milk to $4.07 \mathrm{IU} / \mathrm{mL}$. Both human and formula milk were ceased. The fever declined gradually, she became active, and the abdominal distension and diarrhea improved. Human milk and elemental diet were tolerated, but re-introduction of formula milk induced fever and watery diarrhea again. Urine concentrations of mevalonic acid in the afebrile and febrile periods were elevated to 26.5 and $35.9 \mu \mathrm{g} / \mathrm{mg} \mathrm{Cr}$, respectively. Mevalonate kinase activity with respect to control values was $1.3 \%$ and Mevalonate kinase gene analysis revealed a compound heterozygous mutation [c.613A > G/c.382_383 del AG]. 
In MKD, the inflammasome, which converts pro-IL1 $\beta$ to IL1 $\beta$ and causes fever, is activated excessively by exogenous and endogenous microbial products [4-6]. The disease is caused by the lack of isoprenoids (mevalonate pathway products), and mevalonic aciduria is characteristic. The inflammatory responses in this case were too strong to be induced by milk allergy alone, thus we predicted the co-existence of another inflammatory disease. Although the mechanism is not precisely understood, tissue damage by milk allergy may activate the inflammasome.

At 2 months of age, febrile attack can be avoided by disuse of formula milk. Later, however, attacks may be induced by things such as initiation of vaccinations and common colds. If attacks occur repeatedly, anti-inflammatory drugs such as IL-1 blockers should be introduced to prevent severe complications.

Acknowledgments All the cost of tests and treatment were paid by medical insurance and the parents of the patient.

\section{Compliance with ethical standards}

Conflict of interest All the authors declare that they have no conflict of interest.

Ethical approval This article does not contain any studies with human participants performed by any of the authors.

Informed consent Before gene analysis was performed, we obtained the informed consent about the test from the parents in a written form and also about reporting in publication.

Open Access This article is distributed under the terms of the Creative Commons Attribution 4.0 International License (http:// creativecommons.org/licenses/by/4.0/), which permits unrestricted use, distribution, and reproduction in any medium, provided you give appropriate credit to the original author(s) and the source, provide a link to the Creative Commons license, and indicate if changes were made.

\section{References}

1. Mulders-Manders CM, Simon A (2015) Hyper-IgD syndrome/ mevalonate kinase deficiency: what is new? Semin Immunopathol 37(4):371-376

2. Bader-Meunier B, Florkin B, Sibilia J, Acquaviva C, Hachulla E, Grateau G, Richer O, Farber CM, Fischbach M, Hentgen V, Jego P, Laroche C, Neven B, Lequerré T, Mathian A, Pellier I, Touitou I, Rabier D, Prieur AM, Cuisset L, Quartier P, SOFREMIP (Société Francophone pour la Rhumatologie et les Maladies Inflammatoires en Pédiatrie), CRI (Club Rhumatismes et Inflammations) (2011) Mevalonate kinase deficiency: a survey of 50 patients. Pediatrics 128(1):e152-e159

3. Lainka E, Neudorf U, Lohse P, Timmann C, Bielak M, Stojanov S, Huss K, von Kries R, Niehues T (2012) Incidence and clinical features of hyperimmunoglobulinemia $\mathrm{D}$ and periodic fever syndrome (HIDS) and spectrum of mevalonate kinase (MVK) mutations in German children. Rheumatol Int 32(10):3253-3260

4. van der Burgh R, Ter Haar NM, Boes ML, Frenkel J (2013) Mevalonate kinase deficiency, a metabolic autoinflammatory disease. Clin Immunol 147(3):197-206

5. Tricarico PM, Marcuzzi A, Piscianz E, Monasta L, Crovella S, Kleiner G (2013) Mevalonate kinase deficiency and neuroinflammation: balance between apoptosis and pyroptosis. Int J Mol Sci 14(12):23274-23288

6. Tricarico PM, Crovella S, Celsi F (2015) Mevalonate pathway blockade, mitochondrial dysfunction and autophagy: a possible link. Int J Mol Sci 16(7):16067-16084 